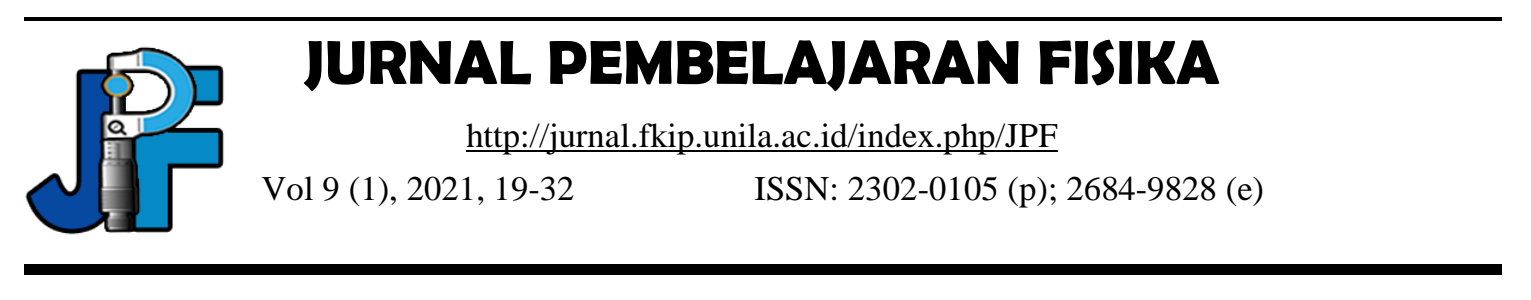

\title{
The Characteristics of The Elevator Motion Based on The Object's Apparent Weight
}

\author{
Alfia Ulfa, Supeno Supeno*, Singgih Bektiarso \\ Universitas Jember, Kalimantan Street No. 37, Kampus Tegalboto, Jember, Jawa Timur, 68121, \\ Indonesia \\ *e-mail: supeno.fkip@unej.ac.id
}

Received: April 22, 2021

Accepted: June 31, 2021

Published: July 19, 2021

\begin{abstract}
This study aims to examine the characteristics of the lift motion based on apparent weight data. This type of research is quantitative research with a survey method. The results showed that the apparent weight change only occurred when the elevator started moving and just before it stopped, acceleration at the beginning of the motion and deceleration at the end of the motion. Elevator has two characteristics of motion; straight motion with constant velocity and straight motion with constant acceleration. Straight motion with constant acceleration consists of accelerated motion that occurs at the beginning of the elavator motion, and straight motion with constant acceleration slowed down at the end of the elevator motion. Meanwhile, straight motion with constant velocity occurs with a longer duration. This study's results have implications for learning physics, one of which can be used as data to develop learning resources for physics in the form of student worksheets.
\end{abstract}

Keywords: Apparent weight, Elevator motion, Newton's law

DOI: http://dx.doi.org/10.23960/jpf.v9.n1.202103 


\section{INTRODUCTION}

Physics as a natural science explains observable phenomena with concepts, laws, and theories based on experience, rationale, and experimentation (Suwindra et al., 2015). Physics is also defined as an experimental science in which physicists must observe natural phenomena to find patterns and principles that connect them to these phenomena (Patriot, 2019; Young et al., 2016). The essence of physics includes curiosity about natural objects and phenomena that cause new problems that can be solved through scientific methods (Erlina et al., 2017). Everyday natural phenomena can be studied and analyzed to study physics concepts because many physics concepts are related to everyday life (Oktaviani et al., 2017; Virani et al., 2018). In learning physics, the material studied in physics is a phenomenon that occurs in nature and is always related to everyday events (Supeno et al., 2017).

Many phenomena in the surrounding environment are related to the principles, theories, or laws of physics, but have not been widely explored and used as contextual learning resources in physics learning. One of the physical phenomena in the environment is the phenomenon of elevator motion. An elevator is a vertical vehicle with periodic movements. It is used to transport (up / down) people or goods through a vertical rail line, generally used in tall buildings (Musyahar et al., 2017). An elevator can save energy and time compared to walking on stairs in tall buildings. The elevator works automatically at a certain speed. When we are in a moving elevator, our gravity will change according to the elevator's movement (Taufiq, 2017). When the elevator moves up, the bodyweight seems to increase, as well as when the elevator moves down; the weight seems to decrease. Meanwhile, when the elevator is at rest, our gravity is still normal. The amount of perceived weight that is felt depends on the elevator floor's upward force to humans (Roy, 2020). Perceived weight is commonly referred to as apparent weight.

Apparent weight can be studied based on Newton's Law of motion. When the elevator is at rest or moving at a constant speed, its acceleration is zero. In this condition, the force equilibrium (Newton's First Law) applies where $\sum \vec{F}_{y}=0$ so that the compressive force of the load acting on the elevator floor is the same as the weight of the load. When the elevator is moving at constant acceleration, the load's weight is not the same as the normal force of the lift on the load. It can be explained using Newton's Second Law where $\sum \vec{F}_{y}=m \vec{a}$ (Pauliza, 2008). The apparent weight in a moving elevator can be used to analyze the characteristics of the elevator motion.

Elevator motion is a physical phenomenon that occurs in real terms in our environment. The elevator motion phenomenon has not been studied extensively, so it can be analyzed for its motion characteristics. In learning physics at school, the phenomenon of elevator motion can be used as a source of contextual learning. Contextual learning resources are needed in physics learning (Astro et al., 2020; Pratiwi et al., 2017) because physics is a natural phenomenon that requires students to understand knowledge contextually (Siswono, 2017). Although there are a lot of physical phenomena in the environment around students that can be used as learning resources (Ramadhani et al., 2019), the teaching materials in some schools mostly emphasize material descriptions rather than applications and do not relate to physics concepts to everyday problems (Wahyuni et al.,2017). Therefore, it is necessary to 
research the characteristics of elevator motion to increase physics learning resources based on physical phenomena in the environment of students. The purpose of this study was to examine the characteristics of the lift motion based on apparent weight.

\section{METHOD}

\section{Research Design \& Procedure}

The type of research is quantitative research with a survey method. The survey method is used to get data from a specific place naturally. Researchers collect data by observing actual events in the form of elevator movements. Data were collected using a digital floor scale, a load of $39.28 \mathrm{~kg}$, a stopwatch, and a smartphone as a recorder. Data acquisition was carried out in 3 different lifts. Elevators 1 and 2 are located in the Center for Development of Advanced Science and Technology (CDAST) building, University of Jember. Elevator 1 reaches a height of 8 floors with a maximum load of $1000 \mathrm{~kg}$ or 15 person. Elevator 2 reaches a height of 8 floors with a whole load of 800 $\mathrm{kg}$. Elevator 3 is in the Postgraduate building, Faculty of Law, University of Jember. Elevator 3 spans five floors with a maximum load of $1150 \mathrm{~kg}$ or 17 person. This research was conducted in several stages, as shown in Figure 1.

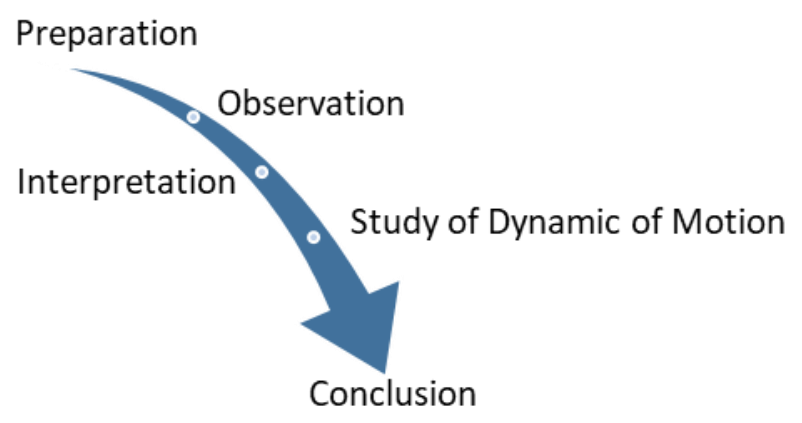

Figure 1. Research stages

The research begins with the preparation stage. At this stage, a literature review is carried out to obtain data, information, and theories that support the research. The literature review is carried out using physics books and scientific journals. The second stage is data acquisition in the field. Data acquisition is an act of measuring the load's weight directly in a moving elevator with a specific travel time. The actual mass of the load used is $39.28 \mathrm{~kg}$. Measurements are made by recording the weight gauge LCD screen and the time when the elevator moves until it stops. Based on these records, the measurement data can be tabulated. The measurement data consists of building height, load weight, elevator travel time, and apparent load weight. The measured data were analyzed for 4 seconds. The balance used has a time response of 3 seconds to obtain valid data. The data must be interpreted with an interval of $\geq 3$ seconds from the time response of the scale. 
Analysis

The measurement result data is then analyzed based on Newton's Second Law equation (Eq. 1) to obtain elevator acceleration data.

$$
\overrightarrow{\mathrm{F}}_{\mathrm{N}}-\overrightarrow{\mathrm{F}}_{\mathrm{g}}=\mathrm{ma}
$$

Based on the lift acceleration data, a study of the lift motion dynamics can be carried out. When the elevator is moving with constant acceleration, it has a straight and regular motion (Prihatini et al., 2017). When the elevator is moving at a constant speed, it has the characteristic of regular straight motion (Handayani et al., 2019)

\section{RESULT AND DISCUSSION}

\section{Elevator 1 at CDAST University of Jember}

Data acquisition in elevator 1 at CDAST University of Jember is carried out in 2 conditions: the elevator moves up and down. The measurement result data is shown in Table 1.

Table 1. Data from elevator 1 at CDAST University of Jember

\begin{tabular}{|c|c|c|c|c|c|}
\hline $\begin{array}{l}\text { Height } \\
\text { (floor) }\end{array}$ & $\begin{array}{c}\text { Direction of } \\
\text { motion }\end{array}$ & $\mathbf{w}(\mathbf{N})$ & $\mathbf{t}(\mathbf{s})$ & $\mathbf{F}_{\mathbf{N}}(\mathbf{N})$ & $a\left(m / s^{2}\right)$ \\
\hline \multirow{10}{*}{8} & \multirow{10}{*}{ To the top } & \multirow{10}{*}{384.94} & 0 & 384.94 & 0,00 \\
\hline & & & 4 & 401,11 & 0,41 \\
\hline & & & 8 & 384,94 & 0,00 \\
\hline & & & 12 & 384,94 & 0,00 \\
\hline & & & 16 & 384,94 & 0,00 \\
\hline & & & 20 & 385,04 & 0,00 \\
\hline & & & 24 & 384,94 & 0,00 \\
\hline & & & 28 & 384,94 & 0,00 \\
\hline & & & 32 & 368,68 & $-0,41$ \\
\hline & & & 36 & 384,94 & 0,00 \\
\hline \multirow{10}{*}{8} & \multirow{10}{*}{ Down } & \multirow{10}{*}{384.94} & 0 & 384,94 & 0,00 \\
\hline & & & 4 & 368,77 & 0,41 \\
\hline & & & 8 & 384,94 & 0,00 \\
\hline & & & 12 & 384,94 & 0,00 \\
\hline & & & 16 & 384,94 & 0,00 \\
\hline & & & 20 & 384,94 & 0,00 \\
\hline & & & 24 & 384,94 & 0,00 \\
\hline & & & 28 & 384,94 & 0,00 \\
\hline & & & 32 & 401,11 & $-0,41$ \\
\hline & & & 36 & 385,14 & 0,00 \\
\hline
\end{tabular}

Based on the research data in Table 1, it can be seen that the travel time when elevator move from the 1st floor to the 8th floor is around $36 \mathrm{~s}$. When the elevator moves vertically upwards, the measured load weight value or apparent weight changes. The changes of apparent weight occur when the elevator starts moving and when the elevator stops. The change of apparent weight occurred at $4 \mathrm{~s}$ and $32 \mathrm{~s}$. In the 8 th to 
28th seconds, the apparent weight is equal to the weight of the real load. The data of apparent weight can be analyzed mathematically to determine the acceleration of the elevator motion. The study was carried out using Newton's second law. Based on the results of the analysis, it can be seen that there is a very significant increase in velocity at $4 \mathrm{~s}$ and a very significant decrease in velocity at $32 \mathrm{~s}$. For intervals $8 \mathrm{~s}$ to $28 \mathrm{~s}$, the elevator moves at zero acceleration. It means that the elevator moves at a constant velocity. When $0 \mathrm{~s}$ and $36 \mathrm{~s}$, the elevator is at rest.

The apparent weight becomes $368.77 \mathrm{~N}$ at $4 \mathrm{~s}$ when the elevator moves vertically downward. At $32 \mathrm{~s}$, the apparent weight becomes $401.11 \mathrm{~N}$. For intervals $8 \mathrm{~s}$ to $28 \mathrm{~s}$, the weight of the load is equal to the real weight. The apparent weight and the elevator travel time are then analyzed mathematically using Newton's Second Law equation to determine the elevator's acceleration. The acceleration of the elevator can be seen in Table 1 . The elevator experiences acceleration only occurs when the elevator starts moving and when it is about to stop.

The research data in Table 1 can be interpreted in the form of a graph of the apparent weight-to-time relationship and the acceleration-time relationship graph shown in Figure 1 to Figure 5.

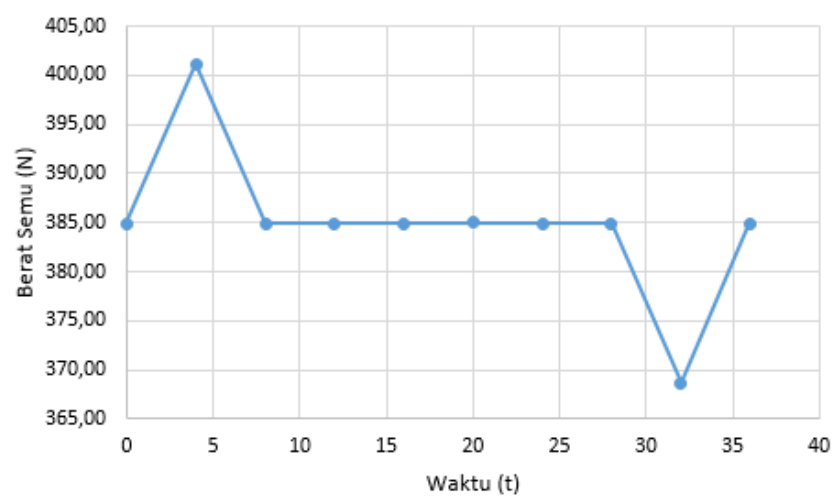

Figure 1. Apparent weight and time in elevator 1 as it moves upward

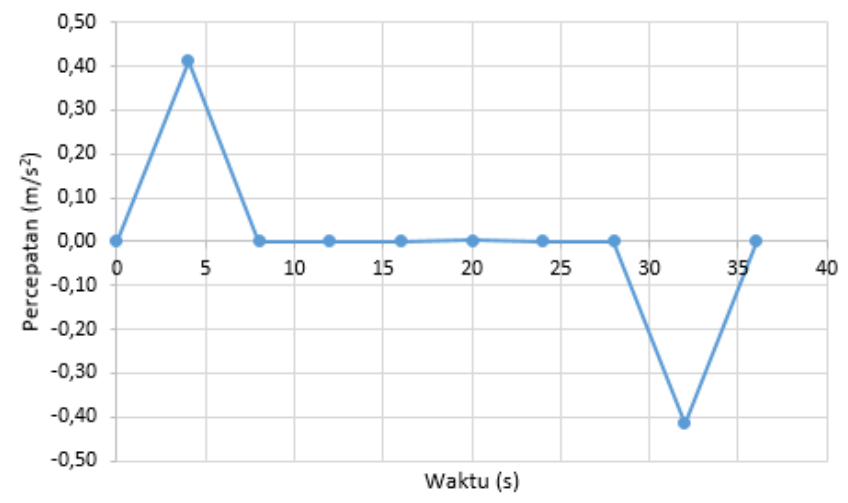

Figure 2. Acceleration and time in elevator 1 as it moves upward 


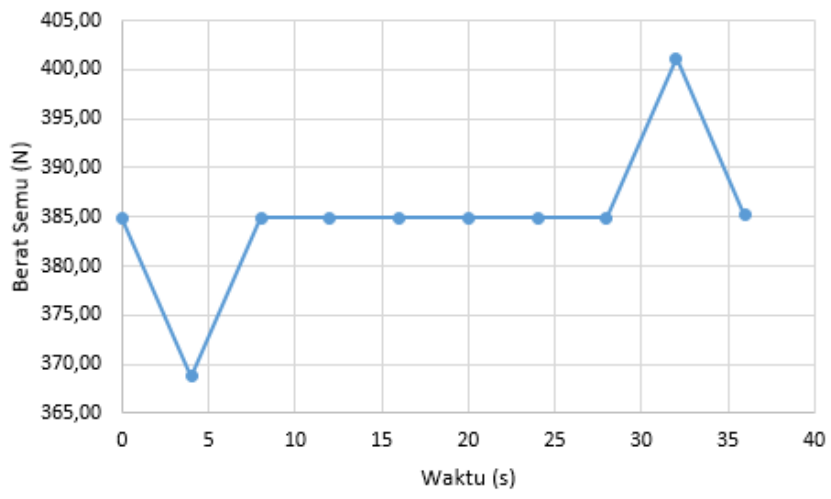

Figure 3. Apparent weight and time in elevator 1 as it moves downward

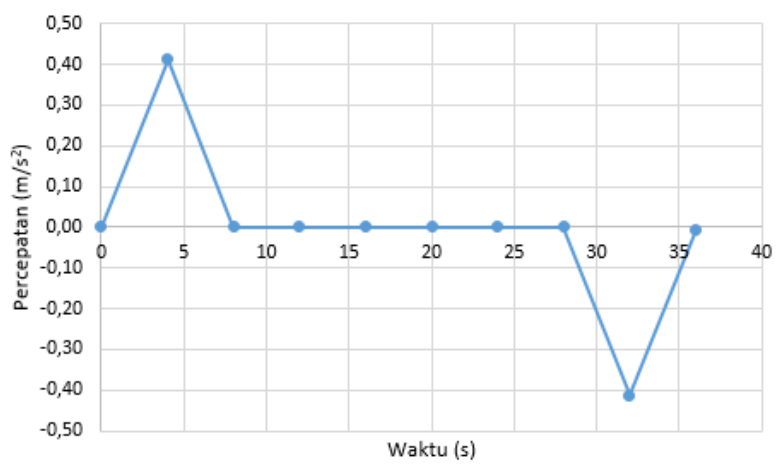

Figure 4. Acceleration and time in elevator 1 as it moves downward

\section{Elevator 2 at CDAST University of Jember}

Data acquisition in elevator 2 at CDAST University of Jember is carried out in 2 conditions: the elevator moves up and down. The measurement result data is shown in Table 2. The apparent weight increases to $399.64 \mathrm{~N}$ at $4 \mathrm{~s}$ when the elevator moves vertically upwards. At a time interval of $8 \mathrm{~s}$ to $28 \mathrm{~s}$, the weight of the load does not change, which is $384.94 \mathrm{~N}$. When the elevator is about to stop, at $32 \mathrm{~s}$, the apparent weight decreases to $370.15 \mathrm{~N}$. The acceleration of the elevator is obtained using Newton's Second Law. The analysis results show that the elevator only experiences acceleration at $4 \mathrm{~s}$ and $32 \mathrm{~s}$, where the elevator acceleration is $0.37 \mathrm{~m} / \mathrm{s}^{2}$ and $-0.38 \mathrm{~m} / \mathrm{s}^{2}$, respectively. A positive sign at $4 \mathrm{~s}$ indicates increasing acceleration, while a negative sign at $32 \mathrm{~s}$ indicates a deceleration of the elevator motion.

The apparent weight changes for intervals $4 \mathrm{~s}$ and $32 \mathrm{~s}$ when the elevator moves vertically downwards. When $4 \mathrm{~s}$, the apparent weight is smaller than the real weight, which is $370.24 \mathrm{~N}$. The apparent weight at $32 \mathrm{~s}$ is greater than the real weight, which is $399.74 \mathrm{~N}$. The elevator accelerates at an interval of $4 \mathrm{~s}$ to $32 \mathrm{~s}$, respectively $0.37 \mathrm{~m} / \mathrm{s}^{2}$. The elevator is accelerating at $4 \mathrm{~s}$, and slowing down at $32 \mathrm{~s}$. 
Table 2. Data from elevator 2 at CDAST University of Jember

\begin{tabular}{|c|c|c|c|c|c|}
\hline Height (floor) & $\begin{array}{c}\text { Direction of } \\
\text { motion }\end{array}$ & $\mathbf{w}(\mathbf{N})$ & $\mathbf{t}(\mathbf{s})$ & $\mathbf{F}_{\mathbf{N}}(\mathbf{N})$ & $\mathbf{a}\left(\mathbf{m} / \mathbf{s}^{2}\right)$ \\
\hline \multirow{10}{*}{8} & \multirow{10}{*}{ To the top } & \multirow{10}{*}{384.94} & 0 & 384,94 & 0,00 \\
\hline & & & 4 & 399,64 & 0,37 \\
\hline & & & 8 & 384,94 & 0,00 \\
\hline & & & 12 & 384,94 & 0,00 \\
\hline & & & 16 & 384,94 & 0,00 \\
\hline & & & 20 & 384,94 & 0,00 \\
\hline & & & 24 & 384,94 & 0,00 \\
\hline & & & 28 & 384,94 & 0,00 \\
\hline & & & 32 & 370,15 & $-0,38$ \\
\hline & & & 36 & 384,94 & 0,00 \\
\hline \multirow{10}{*}{8} & \multirow{10}{*}{ Down } & \multirow{10}{*}{384.94} & 0 & 384,94 & 0,00 \\
\hline & & & 4 & 370,24 & 0,37 \\
\hline & & & 8 & 385,04 & 0,00 \\
\hline & & & 12 & 385,04 & 0,00 \\
\hline & & & 16 & 385,04 & 0,00 \\
\hline & & & 20 & 385,04 & 0,00 \\
\hline & & & 24 & 384,94 & 0,00 \\
\hline & & & 28 & 384,94 & 0,00 \\
\hline & & & 32 & 399,74 & $-0,37$ \\
\hline & & & 36 & 384,94 & 0,00 \\
\hline
\end{tabular}

The research data in Table 2 can be interpreted in the form of a graph of the apparent weight-to-time relationship and the acceleration-time relationship graph shown in Figure 6 to Figure 9.

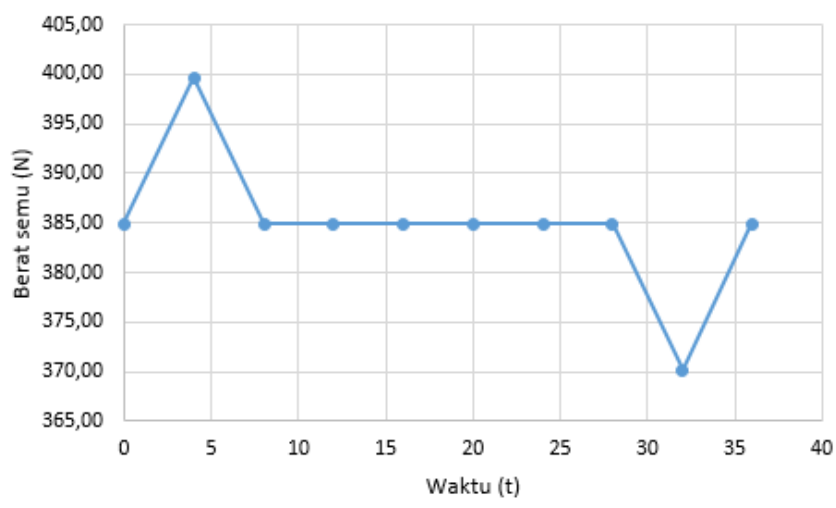

Figure 5. Apparent weight and time in elevator 2 as it moves upward 


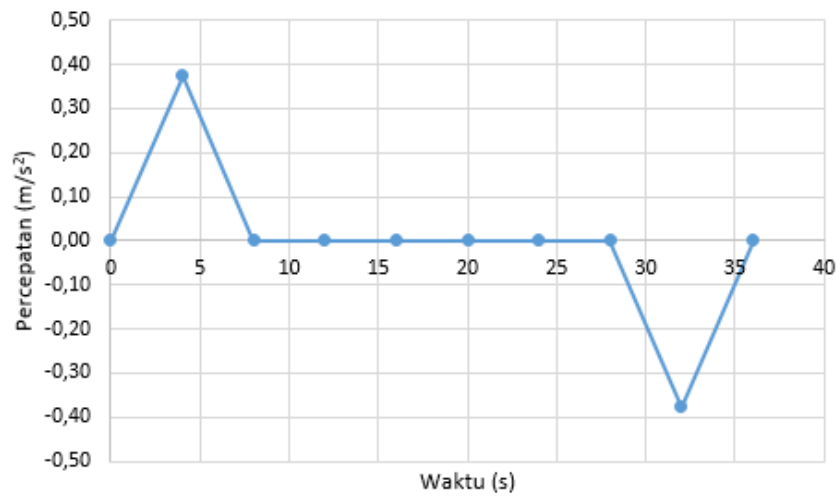

Figure 7. Acceleration and time in elevator 2 as it moves upward

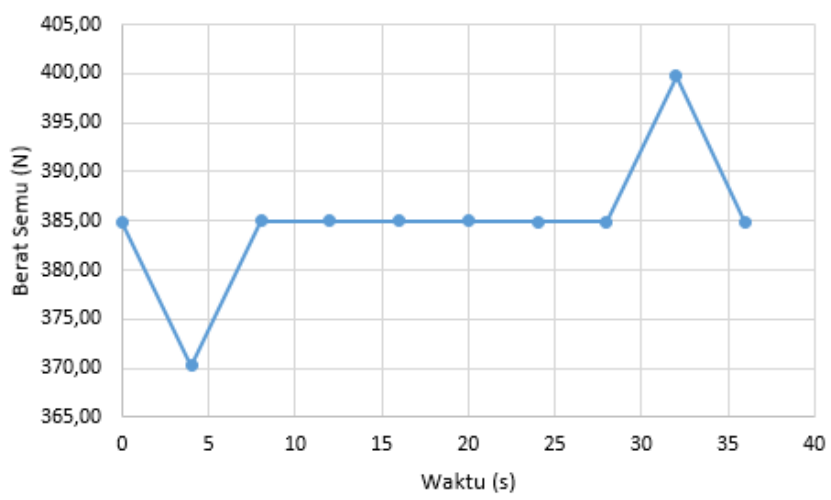

Figure 8. Apparent weight and time in elevator 2 as it moves downward

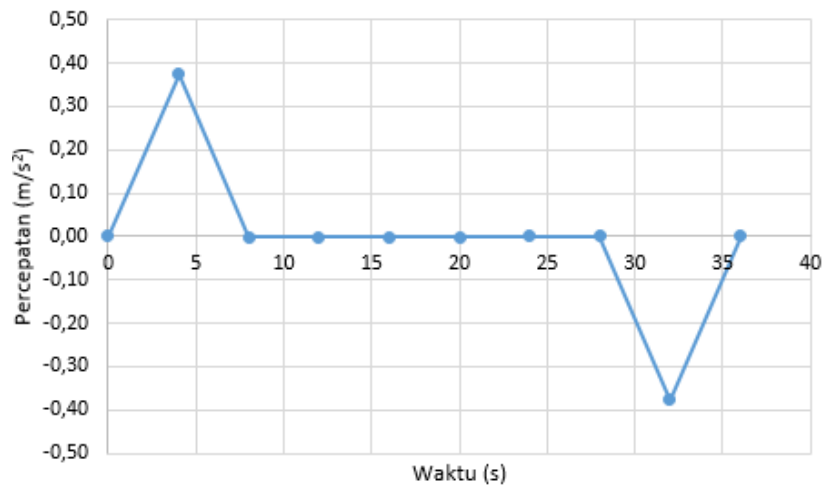

Figure 9. Acceleration and time in elevator 2 as it moves downward

\section{Elevator 3 in Postgraduate building, Faculty of Law, University of Jember}

The third research location is elevator 3 at the Postgraduate building, Faculty of Law, University of Jember. The measurement result data is shown in Table 3. 
Table 3. Data from elevator 3 Postgraduate building, Faculty of Law, University of Jember.

\begin{tabular}{|c|c|c|c|c|c|}
\hline Height (floor) & $\begin{array}{c}\text { Direction of } \\
\text { motion }\end{array}$ & $\mathbf{w}(\mathbf{N})$ & $\mathbf{t}(\mathbf{s})$ & $\mathbf{F}_{\mathbf{N}}(\mathbf{N})$ & $\mathbf{a}\left(\mathbf{m} / \mathbf{s}^{2}\right)$ \\
\hline \multirow{7}{*}{5} & \multirow{7}{*}{ To the top } & \multirow{7}{*}{384.94} & 0 & 384,94 & 0,00 \\
\hline & & & 4 & 406,01 & 0,54 \\
\hline & & & 8 & 384,75 & 0,00 \\
\hline & & & 12 & 384,94 & 0,00 \\
\hline & & & 16 & 384,94 & 0,00 \\
\hline & & & 20 & 363,68 & $-0,54$ \\
\hline & & & 24 & 384,94 & 0,00 \\
\hline \multirow{7}{*}{5} & \multirow{7}{*}{ Down } & \multirow{7}{*}{384.94} & 0 & 384,94 & 0,00 \\
\hline & & & 4 & 363,58 & 0,54 \\
\hline & & & 8 & 384,94 & 0,00 \\
\hline & & & 12 & 384,94 & 0,00 \\
\hline & & & 16 & 384,94 & 0,00 \\
\hline & & & 20 & 406,01 & $-0,54$ \\
\hline & & & 24 & 384,94 & 0,00 \\
\hline
\end{tabular}

Based on the research data in Table 3, it can be seen that the elevator travel time when moving from the 1st floor to the 8th floor is around $24 \mathrm{~s}$. When the elevator moves vertically upwards, the measured load weight value changes. Changes in load weight occur when the elevator starts moving and when the elevator stops. The most significant change in weight value occurred at $4 \mathrm{~s}$ and $20 \mathrm{~s}$. For intervals $8 \mathrm{~s}$ to $16 \mathrm{~s}$, the weight of the load is relatively the same as the weight of the actual load. The apparent weight can be analyzed mathematically to determine the acceleration of the elevator motion. The study was carried out using Newton's second law. Based on the results of the analysis, it can be seen that there is a very significant increase in velocity at $4 \mathrm{~s}$ and a very significant decrease in velocity at $20 \mathrm{~s}$. In the range of $8 \mathrm{~s}$ to $16 \mathrm{~s}$, the elevator moves at zero acceleration. It means that during that time, the elevator moves at a constant velocity. When $0 \mathrm{~s}$ and $20 \mathrm{~s}$, the elevator is at rest.

The apparent weight becomes $363.58 \mathrm{~N}$ at $4 \mathrm{~s}$ when the elevator moves vertically downward. When $20 \mathrm{~s}$, the apparent weight becomes $406.01 \mathrm{~N}$. For intervals $8 \mathrm{~s}$ to $16 \mathrm{~s}$, the weight of the load is relatively the same as the weight of the actual load. The apparent weight and the elevator travel time are then analyzed mathematically using Newton's second law to determine the acceleration of elevator motions. The acceleration of the elevator can be seen in Table 3. The elevator experiences acceleration only occurs when the elevator starts moving and when it is about to stop.

The research data in Table 3 can be interpreted in the form of a graph of the apparent weight-to-time relationship and the acceleration-time relationship graph shown in Figure 10 to Figure 13. 


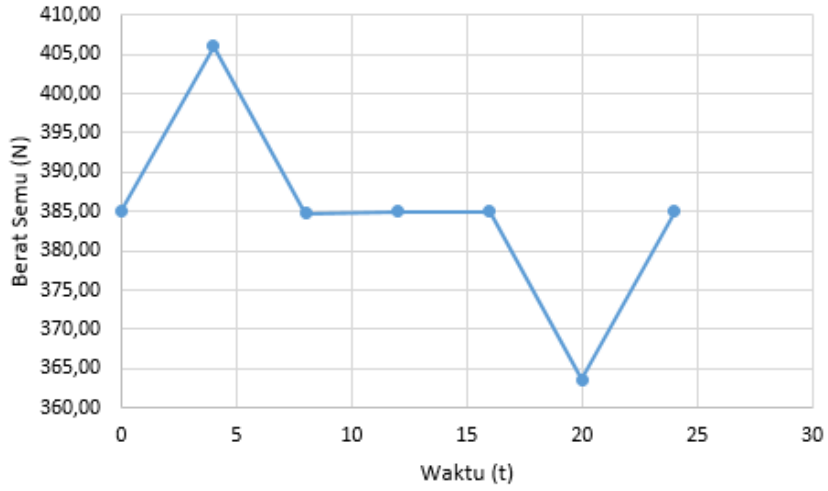

Figure 10. Apparent weight and time in elevator 3 as it moves upward

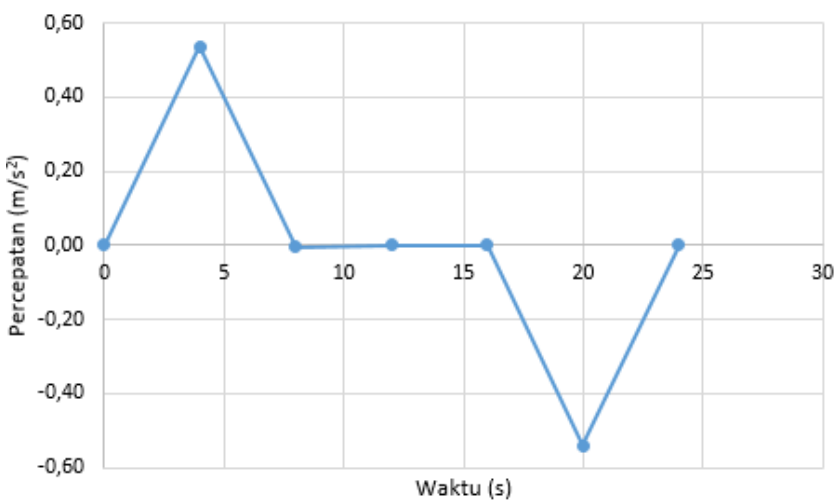

Figure 11. Acceleration and time in elevator 3 as it moves upward

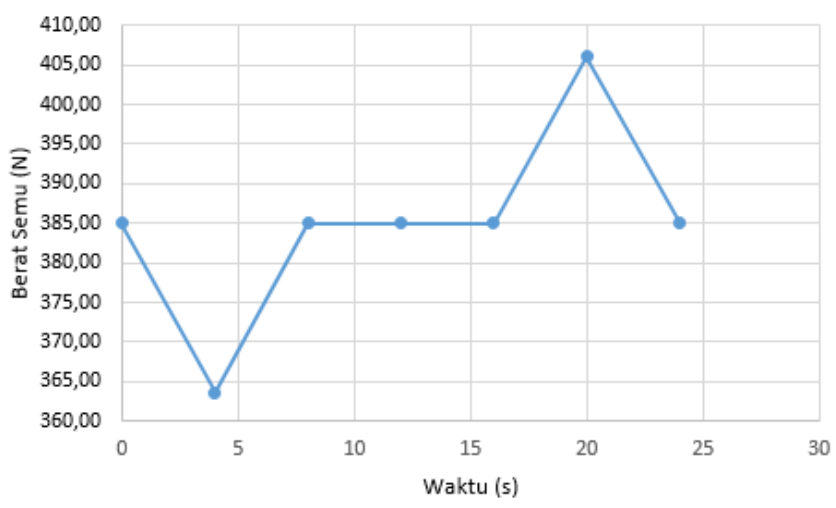

Figure 12. Apparent weight and time in elevator 3 as it moves downward 


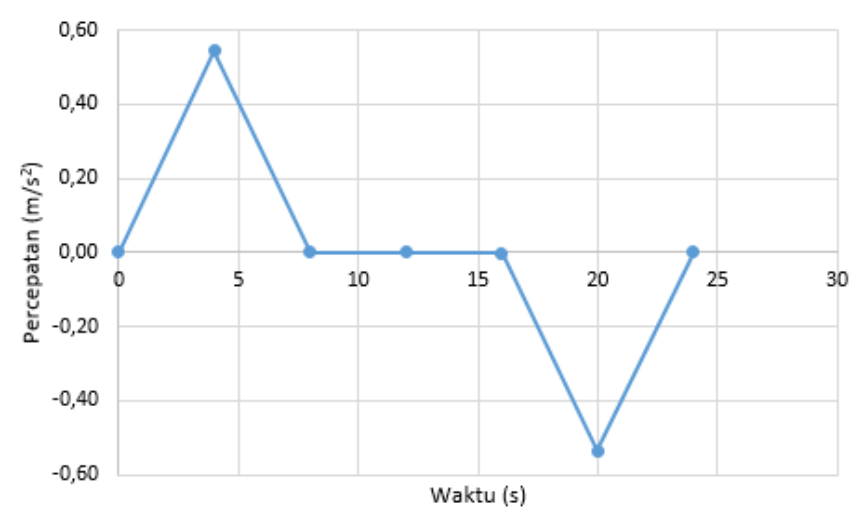

Figure 13. Acceleration and time in elevator 3 as it moves downward

\section{Discussion}

Based on data analysis on the motion of the three elevators, it shows consistent results. Elevator travel time can be divided into three intervals. The first time interval is a condition where the elevator starts moving. The second time interval is a condition for the elevator to move uniformly. The third time interval is a condition for the elevator just before it stops. The apparent weight changes when the elevator moves vertically upward. The apparent weight increases at the beginning of the elevator motion. When the motion is uniform, the apparent weight is equal to the real weight. The apparent weight decreased at the third time interval.

Meanwhile, when the elevator moves vertically downwards, the apparent weight also changes three times. The apparent weight has decreased at the start of the elevator motion. The apparent weight is equal to the real weight when the motion is uniform. The apparent weight decreased at the third time interval. The results of this study are in line with the research conducted by Roy (2020). The number that is read on the weighing screen shows the apparent weight, not the object's actual weight (Halliday et $a l ., 2011)$. This weight is the normal force that the elevator floor exerts on objects when the elevator moves with a certain acceleration. Newton's Second Law applies in the apparent weight phenomenon, where the resultant force on an object is directly proportional to the object's acceleration (Giancoli, 2014).

The apparent weight depends on the acceleration, and it can be positive and negative according to the direction of motion of the elevator. The elevator experiences acceleration when it starts moving upwards so that the weight seems to increase. Shortly before stopping, the elevator is slowing down so that the acceleration is negative. Its condition causes the apparent weight to be less than the actual weight of the object. When the elevator starts moving downwards, the elevator speed increases downward so that it is negative. Its condition causes the apparent weight to be less than the actual weight of the object. Shortly before stopping, the elevator is slowing down so that the acceleration is positive, which causes the apparent weight to be greater than the actual weight.

Based on the analysis of apparent weight data and elevator travel time, acceleration of motion data can be obtained. The elevator is accelerating when it starts 
moving and when it is about to stop. The elevator acceleration is positive at the beginning of its motion and negative at the end of its motion when it moves vertically up or down. This condition indicates that the elevator is accelerated when the elevator starts moving and is slowed down when the elevator is about to stop. The elevator acceleration is zero with a longer duration when the motion is uniform. So, it can be said that the elevator has two characteristics of motion, namely regular straight motion and regular changing straight motion. Straight motion changes regularly consist of two conditions, accelerated motion which occurs at the beginning of the motion, and slowed motion which occurs at the end of the motion. Meanwhile, regular straight motion occurs with a longer duration, namely when the elevator moves constantly.

The apparent weight is the normal force that the lift floor exerts on the load when the elevator is moving at a certain acceleration. If viewed from the rope tension force, the magnitude of the apparent weight is equivalent to the magnitude of the rope tension force. When the elevator is accelerating upward or slowing downward, the tension in the rope is greater than when the elevator is at rest. When the elevator is moving slowed up and accelerated downward, the tension in the rope is less than when the elevator is at rest. When the elevator is moving at constant speed, the tension force on the rope is equal to the tension force on the rope when the elevator is at rest. Meanwhile, when the elevator moves in free fall, the tension in the rope changes to zero. In that condition, someone who is in the elevator will feel weightless.

The implication of research on lift motion in learning physics can be used as a source of contextual physics learning. Learning resources are arranged in the form of worksheets. A simple experimental procedure can be presented in the worksheet regarding the apparent weight of objects in the elevator. The worksheet can be a guide for students to conduct experiments about apparent weight in the elevator. These activities can train skills in applying scientific methods (Supeno et al., 2020) and improve scientific reasoning so that students are able to build their knowledge (Indahsari et al., 2020) and able to solve problems (Efrihani et al., 2017; Fitriyani et al., 2019).

\section{CONCLUSION}

The apparent weight of a load in an elevator can be measured directly on the spot. Based on the apparent weight data, an analysis can be carried out to determine the elevator motion characteristics. In this study, it can be concluded that the elevator has two characteristics of motion; straight motion with constant velocity and straight motion with constant acceleration. Straight motion with constant acceleration consists of accelerated motion and slowed motion. Accelerated motion occurs at the beginning of the elevator motion, while slowed motion occurs just before the elevator stops. Straight motion with constant velocity occurs over a longer duration. The results are expected to provide critical information for physics teachers to develop learning resources in accordance with the phenomenon of elevator motion. Learning resources can be created in the form of worksheets or information corners inserted in textbooks. Contextual phenomena in physics learning resources are expected to help students know the application of physics in everyday life. 


\section{REFERENCES}

Astro, R. B., Doa, H., dan Hendro, H. (2020). Fisika Kontekstual Pembangkit Listrik Tenaga Mikrohidro. ORBITA: Jurnal Kajian, Inovasi Dan Aplikasi Pendidikan Fisika, 6(1), 142-149. https://doi.org/10.31764/orbita.v6i1.1858

Efrihani, S., Rosidin, U., dan Suyatna, A. (2017). Perbandingan Hasil Belajar Fisika Siswa Menggunakan Metode Ekspositori Berbantuan Buku Siswa dengan Metode Inquiry Berbantuan Lembar Kerja Siswa. Jurnal Pembelajaran Fisika, 5(5), 111-120.

Erlina, N., Supeno, dan Iwan,W. (2017). Penalaran Ilmiah dalam Pembelajaran Fisika. Posiding Seminar Nasional Tahun 2016 "Mengubah Karya Akademik Menjadi Karya Bernialai Ekonomi Tinggi”,Universitas Surabaya,Surabaya, 23 Januari 2016, 473-480.

Fitriyani, R. V., Supeno, dan Maryani, M. (2019). Pengaruh LKS Kolaboratif pada Model Pembelajaran Berbasis Masalah terhadap Keterampilan Pemecahan Masalah Fisika Siswa SMA. Berkala Ilmiah Pendidikan Fisika, 7(2), 71-81. https://doi.org/10.20527/bipf.v7i2.6026

Giancoli, D. C. (2014). Physics Principles with Aplication; Seventh Edition. United States of America: Pearson Education.

Halliday, D., Resnick, R., \& Walker, J. (2011). Fundamentals of Physics; Ninth Edition. United States of America: R. R. Donnelley.

Handayani, I. D., Bektiarso, S., dan Astutik, S. (2019). Kajian Kinematika Jalur Wisata Gunung Bromo Melalui Senduro- Lumajang Sebagai E-Suplemen Bahan Ajar Fisika SMA. Seminar Nasional Pendidikan Fisika 2019 "Integrasi Pendidikan, Sains, Dan Teknologi Dalam Mengembangkan Budaya Ilmiah Di Era Revolusi Industri 4.0”, Universitas Jember, Jember, 4(1), 146-151.

Indahsari, S. N., Supeno, dan Maryani. (2020). Student Worksheet Based on Inquiry with Vee Map to Improve Students' Scientific Reasoning Ability in Physics Learning in Senior High School. Journal of Physics: Conference Series, 1465(1), 1-6. https://doi.org/10.1088/1742-6596/1465/1/012036

Musyahar, G., dan Huda, M. (2017). Prototype Pembelajaran Lift Tiga Lantai Berbasis Arduino. Jurnal Cahaya Bagaskara, 1(1), 18-21. https://jurnal.umpp.ac.id/index.php/cahaya_bagaskara/article/view/391/251

Oktaviani, W., Gunawan, dan Sutrio, S. (2017). Pengembangan Bahan Ajar Fisika Kontekstual untuk Meningkatkan Penguasaan Konsep Siswa. Jurnal Pendidikan Fisika Dan Teknologi, $\quad 3(1), \quad 1-7$. http://jurnalfkip.unram.ac.id/index.php/JPFT/article/view/320

Patriot, E. A. (2019). Analisis Level Pemahaman Siswa pada Konsep Usaha dan Energi Melalui Penerapan Pembelajaran Konseptual Interaktif dengan Pendekatan Multirepresentasi. JIFP (Jurnal Ilmu Fisika Dan Pembelajarannya), 3(1), 3441. 
Pauliza, O. (2008). Fisika Kelompok Teknologi dan Kesehatan untuk Sekolah Menengah Kejuruan Kelas X. Bandung: Grafindo Media Pratama.

Pratiwi, R. I., Nyeneng, I. D. P., dan Wahyudi, I. (2017). Pengembangan Modul Pembelajaran Kontekstual Berbasis Multiple Representations pada Materi Fluida Statis. Jurnal Pembelajaran Fisika, 5(3), 69-79.

Prihatini, S., Handayani, W., dan Agustina, R. D. (2017). Identifikasi Faktor Perpindahan Terhadap Waktu Yang Berpengaruh Pada Kinemetika Gerak Lurus Beraturan (Glb) Dan Gerak Lurus Berubah Beraturan (Glbb). Journal of Teaching and Learning Physics, 2(2), 13-20. https://doi.org/10.15575/jotalp.v2i2.6580

Ramadhani, P. R., Akmam, Desnita, dan Y. Darvina. (2019). Analisis Keterampilan Proses Sains pada Buku Teks Pelajaran Fisika SMA Kelas XI Semester 1. Pillar of Physic Education, 12(4), 649-656.

Roy, S. (2020). A Theoretical Study on the Perception of Weight in a Moving Elevator. International Journal of Contemporary Research and Review, 11(04), 2018920200.

Siswono, H. (2017). Analisis Pengaruh Keterampilan Proses Sains Terhadap Penguasaan Konsep Fisika Siswa. Momentum: Physics Education Journal, 1(2), 83-90. https://doi.org/10.21067/mpej.v1i2.1967

Supeno, Kurnianingrum, A. M., dan Cahyani, M. . (2017). Kemampuan Penalaran Berbasis Bukti dalam Pembelajaran Fisika. Jurnal Pembelajaran Dan Pendidikan Sains, 2(1), 64-78.

Supeno, Astutik, S., dan Lesmono, A. D. (2020). Pre-service Science Teachers' Understanding of Scientific Method for Studying Local Environmental Issues. IOP Conference Series: Earth and Environmental Science, 485(1), 1-6. https://doi.org/10.1088/1755-1315/485/1/012033

Suwindra, I. N. P., R. Sujanem, dan I. S. (2015). Pengembangan Modul Software Multimedia Interaktif dengan Strategi Pembelajaran Berbasis Masalah untuk Meningkatkan Pemahaman Konsep dan Hasil Belajar Fisika Siswa Kelas XII SMA. JPI (Jurnal Pendidikan Indonesia), I(1), 13-27. https://doi.org/10.23887/jpi-undiksha.v1i1.4483

Taufiq. (2017). Eksperimen Berpikir (Thought Experiments); Beberapa Kasus dalam Hukum Newton. Prosiding Seminar Nasional Pendidikan IPA 2017, 150-162.

Virani, W. S., Supeno, S., dan Supriadi, S. (2018). Kajian Kinematika Gerak pada Jalur Lokasi Kecelakaan Berisiko Tinggi (Blackspot) sebagai Sumber Belajar Fisika di SMA. Jurnal Riset Dan Kajian Pendidikan Fisika, 5(1), 22-29.

Wahyuni, A. I., B. Astuti, dan D. Y. (2017). Bahan ajar fisika berbasis I-SETS (islamic, science, environment, technology, society) terintegrasi karakter. Unnes Physics Education Journal, 6(3), 17-25.

Young, H. D., dan Freedman. R. A. (2016). University Physics with Modern Physics (14th ed.). pearson. 